Jurnal Care Vol .6, No.1,Tahun 2018

\title{
Penurunan Postpartum Blues Dan Ansietas Melalui Terapi Thought Stopping Dan Terapi Suportif Pada Ibu Postpartum Dengan Bayi Prematur
}

\author{
Sri Laela ${ }^{1}$, Budi Anna Keliat ${ }^{2}$, Mustikasari ${ }^{3}$ \\ Program Magister Ilmu Keperawatan Universitas Indonesia \\ e-mail: srilaela13@gmail.com
}

\begin{abstract}
Postpartum mothers with premature babies born sectio caesaria will require a more adaptation process compared to normal postpartum mothers who gave birth to term infants. Postpartum mothers of premature infants mostly are at risk for postpartum blues and anxiety. The purpose of this study identified the effect of thought-stopping and supportive therapies on mothers of premature infants with postpartum blues and maternal anxiety. The research design used quasi-experiment with control group pretest-posttest design with consecutive sampling method. The research method used a quasi-experimental control group pretest-posttest design with consecutive sampling. The sample in this study was postpartum mothers with premature baby treated in Perina - Nicu room as many as 62 respondents, taken by convenience sampling. The instruments used in this study are HARS and EPDS. The instruments used in this study are HARS and EPDS. The results showed differences in postpartum blues and anxiety levels of postpartum mothers with premature infants significant ( $p$-value $=0.000)$ between the groups thought-stopping therapy and supportive therapy with groups that receive nursing actions. Thought-stopping and supportive therapies can reduce mothers postpartum blues and anxiety with preterm infants twice as large as Ners nursing care.
\end{abstract}

Keywords: Anxiety; postpartum blues;supportive therapy;thought stopping

\begin{abstract}
ABSTRAK
Ibu postpartum dengan bayi prematur yang lahir secara sectio caesaria akan membutuhkan proses adaptasi yang lebih dibandingkan dengan ibu postpartum normal yang melahirkan bayi cukup bulan. Ibu postpartum dengan bayi prematur berisiko mengalami postpartum blues dan ansietas. Tujuan penelitian ini mengidentifikasi pengaruh terapi thought stopping dan terapi suportif terhadap postpartum blues dan ansietas ibu postpartum dengan bayi prematur. Desain penelitian yang digunakan quasi-experiment with control group pretest-posttest design dengan metode consecutive sampling. Sampel dalam penelitian ini adalah ibu postpartum dengan bayi prematur yang dirawat di ruang Perina - Nicu sebanyak 62 responden, diambil melalui convenience sampling. Instrumen yang digunakan dalam penelitian ini adalah HARS dan EPDS.Hasil penelitian menunjukkan ada penurunan postpartum blues dan ansietas secara bermakna ( $\mathrm{p}$-value $=0,000)$ pada kelompok yang mendapat tindakan keperawatan Ners, terapi thought stopping dan terapi suportif, dan lebih besar penurunan secara bermakna dibandingkan dengan kelompok yang hanya mendapat tindakan keperawatan Ners. Terapi thought stopping dan terapi suportif mampu menurunkan postpartum blues dan ansietas ibu postpartum dengan bayi prematur dua kali lebih besar dibanding pemberian tindakan keperawatan Ners.
\end{abstract}

Kata kunci: Ansietas;postpartum blues;terapi suportif;thought stopping 


\section{PENDAHULUAN}

Periode postpartum merupakan masa krisis bagi ibu, suami dan keluarga akibat adanya perubahan fisik, psikologis dan struktur keluarga yang membutuhkan proses adaptasi atau penyesuaian (Murray \& McKinney, 2007). Proses adaptasi fisiologis dimulai sejak ibu melahirkan bayinya hingga kembalinya fungsi tubuh pada kondisi saat sebelum hamil, yaitu dalam kurun waktu 6 sampai 8 minggu (Pilliteri, 2010).

Ibu postpartum dengan bayi prematur yang lahir secara sectio caesaria akan membutuhkan proses adaptasi yang lebih dibandingkan dengan ibu postpartum normal yang melahirkan bayi cukup bulan. Hal ini dikarenakan ibu dengan post sectio caesaria akan menjalani masa nifas dengan dua permasalahan, yaitu proses pemulihan pasca persalinan dan penyembuhan luka operasi yang terdapat di bagian abdomen (Syaifuddin, 2006), dan ditambah lagi dengan kondisi bayi prematur yang membutuhkan perawatan khusus.WHO (2010) memperkirakan 15 juta kelahiran atau $12 \%$ dari semua kelahiran di dunia adalah prematur. Tingkat tertinggi kelahiran prematur terjadi di India sekitar $11,9 \%$ dan terendah terjadi di Eropa $6,2 \%$. Indonesia menempati urutan kelima terbanyak dalam melahirkan bayi prematur. Data badan kesehatan dunia (WHO, 2013 ) menyatakan dari 100 bayi yang lahir di Indonesia sebanyak 16 bayi mengalami kelahiran prematur.

Riskesdas ( 2013 ) menyatakan bahwa prevalensi bayi dengan berat badan lahir rendah (BBLR) sebesar 11,1\% pada tahun 2010. Angka kelahiran bayi prematur \& BBLR di Indonesia sekitar 27,9\% (Wijayanegara,2010). Seperlima bayi yang lahir usia gestasi $<32 \mathrm{mg}$ tidak bertahan hidup ditahun pertama, sejumlah $75-80 \%$ meninggal pada usia $<28$ hari dan 0,3\% kematian bayi yang lahir pada usia cukup bulan (Wijayanegara,2009).

Ibu postpartum juga mengalami adaptasi psikologis. Menurut Rubin dalam Varney (2007) menyatakan bahwa adaptasi psikologis terbagi atas tiga fase, yaitu : fase taking in (ketergantungan), fase taking bold (ketergantungan mandiri) dan fase letting go (kemandirian), ketiga fase tersebut akan terlewati dengan baik jika ibu postpartum memperoleh dukungan sosial dari orangorang disekitarnya.Ibu postpartum yang gagal dalam fase taking In akan menyebabkan postpartum blues (Bobak, 2005). Gejala yang dimunculkan pada postpartum blues seperti reaksi sedih, mudah menangis, cemas, mudah tersinggung, perasaan labil, cenderung 
menyalahkan diri sendiri, merasa tidak mampu, gangguan pola tidur, tidak nafsu makan. Gejala ini akan muncul setelah persalinan dan akan berlangsung dalam rentang waktu 14 hari. Pada ibu primipara dan ibu post sectio caesaria rentan sekali terjadinya postpartum blues.

Ansietas merupakan gangguan psikososial yang sering terjadi pada setiap individu (Videbeck, 2011). Penelitian yang dilakukan oleh Eutrope, Thierry, Lempp, Laurence, (2014) tentang Emotional Reactions of Mothers Facing Premature Births:Study of 100 Mother-Infant Dyads 32 Gestational Weeks, dihasilkan bahwa orang tua bayi prematur mengalami ansietas yang berhubungan dengan berat badan bayi yang rendah dan membutuhkan dukungan sosial sebelum pulang kerumah.

Terapi individu yang efektif dalam mengatasi ansietas adalah CT, BT, Thought stopping, dan CBT (Varcolis, 2006). Terapi thought stopping merupakan sebuah tehnik penghentian pikiran yang dipelajari sendiri oleh ibu postpartum yang dapat digunakan ketika ingin menghilangkan pikiran yang mengganggu atau negatif dan pikiran yang tidak diinginkan secara sadar (Townsend, 2009).
Terapi suportif merupakan suatu bagian dari psikoterapi yang digunakan pada komunitas berbasis kesehatan jiwa (Viederman, 2008). Tujuan terapi suportif yaitu meningkatkan individu yang suportif, meningkatkan kekuatan individu, keterampilan koping dan menggunakan sumber-sumber koping. Justifikasi pemilihan kedua terapi ini dikarenakan pada ibu postpartum dengan bayi prematur ditemukan adanya pikiran yang mengganggu akibat kondisi bayi yang dirawat di Perina - Nicu yang membuat ansietas dan permasalahan yang dihadapi ibu postpartum dengan bayi prematur tidak hanya saat bayi dirawat di Perina $\mathrm{Nicu}$, tetapi juga setelah bayi prematur pulang kerumah. Hal ini disebabkan karena perawatan bayi prematur membutuhkan waktu yang cukup lama, sehingga ibu postpartum membutuhkan dukungan internal / eksternal secara terus menerus.

Untuk mengatasi masalah ansietas dan mengetahui apakah ibu postpartum dengan bayi prematur mengalami postpartum blues atau tidak, maka peneliti mengukur tanda - tanda ansietas dan postpartum blues pada ibu postpartum dengan bayi prematur diruang Perina Nicu kemudian melakukan tindakan keperawatan Ners, terapi thought stopping 
dan terapi suportif.Pertanyaan penelitian yang muncul adalah apakah tindakan keperawatan Ners, thought stopping dan terapi suportif berpengaruh dalam mengatasi postpartum blues dan ansietas ibu postpartum dengan bayi prematur diruang Perina -Nicu ?

\section{METODE PENELITIAN}

Desain dalam penelitian ini menggunakan desain quasi-experiment with control group pretest-posttest design yang melihat pengaruh tindakan keperawatan Ners, terapi thought stopping dan terapi suportif terhadap postpartum blues dan ansietas ibu postpartum dengan bayi prematur diruang Perina Nicu. Metode sampling yang digunakan adalah convenience sampling, jumlah sampel 62 responden. Total waktu penelitian 25 minggu, yaitu mulai Desember - Juni 2016. Instrumen yang digunakan dalam penelitian ini adalah HARS dan EPDS.

\section{HASIL}

Karakteristik usia ibu postpartum rata-rata 32 tahun dengan usia termuda 22 tahun dan usia tertua 39 tahun, tingkat pendidikan paling banyak adalah akademik/ perguruan tinggi sebanyak 57 orang (95\%), cara pembayaran paling banyak adalah asuransi sebesar 27 orang $(43,5 \%)$, sebagian besar riwayat usia kehamilan berada pada usia kehamilan 36-37 minggu sebanyak 30 orang (48,3\%). Riwayat persalinan paling banyak adalah sectio caesarea yakni 43 (69,4\%). Paritas paling banyak adalah multipara sekitar 37 orang $(59,7 \%)$. Sistem pendukung paling banyak adalah anggota keluarga sebanyak 49 orang $(79 \%)$.

Hasil uji statistik kesetaraan ibu postpartum berdasarkan usia, pendidikan, cara pembayaran, riwayat usia kehamilaan, paritas, riwayat persalinan dan sistem pendukung didapatkan $\mathrm{p}$ value $>0,005$ sehingga disimpulkan bahwa karakteristik ibu postpartum pada kelompok intervensi setara dengan kelompok kontrol.

Kondisi postpartum blues dan ansietas ibu postpartum dengan bayi prematur sebelum dilakukan tindakan keperawatan Ners dan terapi thought stopping pada kelompok intervensi dan tindakan keperawatan Ners pada kelompok kontrol didapatkan data bahwa rata-rata ibu postpartum mengalami pospartum blues sebesar 55,43\% dan rata- rata tingkat Ansietas sebesar 50,92\% menunjukan ansietas berat.

Hasil uji statistik kesetaraan ibu postpartum berdasarkan pospartum blues dan ansietas didapatkan ( $\mathrm{p}$ value $>0,05$ ), 
sehingga disimpulkan bahwa pospartum blues dan ansietas kelompok intervensi setara dengan kelompok kontrol.

Perbedaan postpartum blues dan ansietas ibu postpartum sebelum dan sesudah dilakukan tindakan keperawatan Ners, terapi thought stopping pada kelompok intervensi dan tindakan keperawatan Ners pada kelompok kontrol dapat terlihat pada Tabel. 1

Berdasarkan Tabel 1 didapatkan data bahwa setelah dilakukan tindakan keperawatan Ners dan terapi thought stopping menunjukkan ada penurunan rata rata yang siginifikan pada ansietas sebesar $14,46 \%$ dari ansietas berat menjadi ansietas sedang dan pospartum blues turun sebesar 12,68\%. Nilai tesebut masih berada pada rentang postpartum blues.Setelah dilakukan tindakan keperawatan Ners menunjukkan ada penurunan rata - rata yang siginifikan pada ansietas sebesar 12,32\% yang berarti dari ansietas berat menjadi ansietas sedang dan pospartum blues menurun 8,06\%. Nilai tesebut masih berada pada rentang postpartum blues.Penurunan tingkat postpartum blues dan ansietas pada kelompok ibu postpartum yang mendapatkan tindakan keperawatan Ners dan terapi thought stopping lebih besar secara bermakna dibandingkan dengan yang hanya mendapatkan tindakan keperawatan Ners ( $\mathrm{p}$ value $<0,05)$.

Tabel.1 Perbedaan postpartum blues dan ansietas ibu postpartum antara sebelum dan sesudah dilakukan tindakan keperawatan Ners, terapi thought stopping dengan tindakan keperawatan Ners $(\mathrm{n}=62)$

\begin{tabular}{lcll}
\hline Variabel & $\begin{array}{c}\text { Mean } \\
\text { Sebelum }\end{array}$ & $\begin{array}{l}\text { Mean } \\
\text { Sesudah }\end{array}$ & P value \\
\hline Postpartum blues & PP.blues & PP.blues & 0,038 \\
Ners & PP.blues & PP.blues & \\
Ners, TS & & & \\
Ansietas & Berat & Sedang & 0,032 \\
Ners & Berat & Sedang & \\
Ners, TS & & & \\
\hline
\end{tabular}

Perbedaan postpartum blues dan ansietas ibu postpartum antara sesudah dilakukan tindakan keperawatan Ners, terapi thought stopping dengan tindakan keperawatan Ners, terapi thought stopping dan terapi suportif pada kelompok intervensi dapat dilihat pada Tabel 2

Hasil uji statistik pada Tabel 2 menunjukkan bahwa setelah dilakukan 
Jurnal Care Vol .6, No.1,Tahun 2018

tindakan keperawatan Ners, terapi thought stopping dan terapi suportif ada penurunan rata - rata yang siginifikan pada ansietas sebesar $17,57 \%$ yang berarti dari ansietas sedang menjadi ansietas normal dan pospartum blues nilai menurun 16,33\%, yang berarti dari kondisi postpartum blues menjadi tidak postpartum blues /
normal.Hasil penelitian menunjukan bahwa pemberian terapi thought stopping dan terapi suportif mampu menurunkan postpartum blues dan ansietas ibu postpartum 2x lebih besar dibandingkan dengan pemberian tindakan keperawatan Ners.

Tabel. 2 Perbedaan Postpartum Blues dan Ansietas Ibu Postpartum antara Sesudah Dilakukan Tindakan Keperawatan Ners, Terapi Thought Stopping dengan Tindakan Keperawatan Ners, Terapi Thought Stopping dan Terapi Suportif Pada Kelompok Intervensi

\begin{tabular}{llll}
\hline Variabel & Mean & SD & P.Value \\
\hline Postpartum blues & & & \\
Sesudah (, Ners, TS) & PP.blues & 3,049 & 0,000 \\
Sesudah (Ners, TS, S) & Normal & 3,294 & \\
Ansietas & & & \\
Sesudah (Ners, TS) & Sedang & 4,089 & 0,000 \\
Sesudah (Ners, TS, S) & Normal & 4,856 & \\
\hline
\end{tabular}

\section{PEMBAHASAN}

Hasil penelitian menunjukan bahwa mereka mengalami kesulitan menjadi sebelum dilakukan tindakan keperawatan Ners dan terapi Thought stopping menunjukan bahwa semua ibu postpartum dengan bayi prematur diruang Perina - Nicu mengalami postpartum blues dan ansietas berat.Hasil penelitian yang berjudul "Experiences of having a prematurely born infant from the perspective of mothers in Northern Sweden", yang dilakukan oleh Lindberg dan Ohrling (2008) menguatkan hasil penelitian ini. Didapatkan hasil bahwa ibu tidak siap memiliki bayi yang lahir prematur dan seorang ibu pada masa awal pasca melahirkan. Ibu mengalami perasaan kecemasan dengan adanya pemisahan dari bayinya.Penelitian Melynk, Feinstein \& Fairbanks, (2007) menyebutkan bahwa hospitalisasi perawatan di ruang Nicu berdampak negatif bagi kondisi psikologis orang tua dan perkembangan bayi prematur di kemudian hari. Dampak negatif tersebut antara lain ansietas tingkat tinggi dan gejala depresi, kehilangan kepercayaan diri dalam perawatan bayi karena kurangnya informasi. 
Jurnal Care Vol .6, No.1,Tahun 2018

Pengaruh tindakan keperawatan Ners dan terapi thought stopping terhadap postpartum blues dan ansietas ibu postpartum dengan bayi prematur

Postpartum blues pada ibu postpartum dengan bayi prematur yang mendapatkan tindakan keperawatan Ners dan terapi thought stopping terjadi penurunan nilai postpartum blues sebesar 12,68\% yang artinya masih postpartum blues dan pada ibu postpartum yang tidak mendapatkan terapi thought stopping penurunan nilai postpartum blues sebesar 8,06\%, yang artinya masih postpartum blues. Penurunan nilai postpartum blues pada kelompok ibu postpartum yang mendapatkan tindakan keperawatan Ners dan terapi thought stopping lebih besar secara bermakna dibandingkan dengan yang hanya mendapatkan tindakan keperawatan Ners ( $\mathrm{p}$-value $<0,05)$.

Hasil penelitian menunjukan bahwa ansietas pada ibu postpartum yang mendapatkan tindakan keperawatan Ners dan terapi thought stopping terjadi penurunan nilai ansietas sebesar 14,46\%, yang artinya dari ansietas berat menjadi sedang dan pada ibu postpartum yang tidak mendapatkan terapi thought stopping penurunan nilai ansietas sebesar 12,32\%, yang artinya dari ansietas berat menjadi sedang.Penurunan tingkat ansietas pada penelitian ini sejalan dengan hasil penelitian yang dilakukan oleh Agustarika (2009) tentang pengaruh terapi thought stopping terhadap tingkat ansietas pada klien dengan penyakit fisik di RSUD Sorong menyebutkan bahwa adanya penurunan ansietas secara bermakna pada klien yang mendapat terapi thought stopping yang meliputi respon fisiologis, kognitif, perilaku dan emosi. Penelitian lain yang mendukung hasil penelitian ini adalah penelitian Bakker (2009) "In defence of thought stopping", dihasilkan bahwa thought stopping mampu menekan tingkat ansietas dan meningkatkan koping individu. Penelitian yang sejalan dengan penelitian ini juga dilakukan oleh Naikare \& Kale (2015) "Thought Stopping Activity as Innovative Trend to Deal with Stresses", dihasilkan bahwa tehnik penghentian pikiran mampu mengendalikan tingkat stres pekerja industri.

Berdasarkan data tersebut dapat disimpulkan bahwa tindakan keperawatan Ners dan terapi thought stopping mampu menurunkan postpartum blues dan tingkat ansietas ibu postpartum dengan bayi prematur. Penurunan tingkat ansietas pada kelompok ibu postpartum yang mendapatkan tindakan keperawatan Ners dan terapi thought stopping lebih besar secara bermakna dibandingkan dengan 
yang hanya mendapatkan tindakan keperawatan Ners.

\section{Pengaruh tindakan keperawatn Ners terhadap postpartum blues dan ansietas ibu postpartum dengan bayi prematur}

Hasil penelitian menunjukkan ada penurunan rata - rata yang siginifikan pada ansietas dari ansietas berat menjadi ansietas sedang dan nilai pospartum blues setelah tindakan keperawatan Ners menurun $8,06 \%$, yang artinya masih postpartum blues.Hasil penelitian ini sejalan dengan penelitian yang dilakukan oleh Bektas (2008) yang menyebutkan bahwa pendidikan kesehatan mempunyai pengaruh yang signifikan terhadap tingkat ansietas.. Sebuah penelitian yang dilakukan oleh Fiandini (2010) menemukan bahwa relaksasi nafas dalam mampu secara efektif menurunkan tingkat ansietas pasien pre operasi di ruang bedah. Hasil tersebut sesuai dengan pernyataan Prawitasari (2002) yang mengungkapkan bahwa teknik relaksasi juga dapat digunakan sebagai keterampilan koping yang aktif dalam kondisi ansietas. Penelitian tentang teknik reduksi ansietas lainnya, diungkapkan pula oleh Mu`afiro (2004). Hasil dari penelitian tersebut membuktikan bahwa teknik hipnotis lima jari cukup efektif untuk menurunkan tingkat ansietas pasien kanker leher rahim di ruang kandungan RSU Dr Soetomo Surabaya.Berdasarkan data tersebut dapat disimpulkan bahwa tindakan keperawatan Ners dapat menurunkan nilai postpartum blues dan tingkat ansietas pada ibu postpartum dengan bayi prematur.

\section{Pengaruh tindakan keperawatan Ners, thought stopping dan terapi suportif terhadap postpartum blues dan ansietas ibu postpartum dengan bayi prematur.}

Setelah dilakukan tindakan keperawatan Ners, terapi thought stopping dan terapi kelompok suportif hasil penelitian menunjukkan ada penurunan rata - rata yang lebih siginifikan pada ansietas sebesar 32,14\% yang berarti dari ansietas berat menjadi ansietas normal dan pospartum blues nilai menurun 29,03\%, yang berarti dari kondisi postpartum blues menjadi normal atau tidak postpartum blues.Dochterman (2008) menjelaskan bahwa salah satu psikoterapi yang dapat dipergunakan untuk mengatasi ansietas terutama pada masalah emosional dan berfokus pada bagaimana memfasilitasi klien untuk mengenal dan mempergunakan suport sistem yang mampu dijangkau adalah terapi suportif. 
Penelitian lain yang mendukung hasil penelitian ini adalah penelitian yang dilakukan oleh Banowati (1989). Banowati menyatakan bahwa psikoterapi suportif yang dilakukan pada pasien hemiparase mampu menurunkan derajat depresi dan ansietas serta meningkatkan semangat hidup. Penelitian serupa yang dilakukan oleh Hasmilasari (2010) membuktikan juga bahwa dengan terapi suportif tingkat ansietas pada ibu hamil mengalami penurunan. Sedangkan penelitian lainnya yang pernah dilakukan oleh Shechtman dan Katz (2007) membuktikan bahwa terapi kelompok suportif cukup efektif untuk menurunkan tingkat ansietas sekelompok remaja yang mengalami gangguan belajar dalam membangun hubungan sosial dan persahabatan dengan orang lain. Berdasarkan hasil tersebut dapat disimpulkan bahwa terapi thought stopping dan terapi suportif mampu menurunkan postpartum blues dan tingkat ansietas ibu postpartum dengan bayi prematur $2 \mathrm{x}$ lebih besar dibandingkan hanya mendapat tindakan keperawatan Ners.

\section{KESIMPULAN}

1. Karakteristik ibu postpartum dengan bayi prematur di ruang Perina - Nicu rata-rata berusia 32 tahun, pendidikan akademi / Perguruan
Tinggi, cara pembayaran asuransi, paritas multipara, riwayat usia kehamilan 36-37 minggu, riwayat persalinan SC, sumber pendukung yang didapat dari keluarga, mayoritas mengalami postpartum blues dan ansietas berat.

2. Tindakan keperawatan Ners dan terapi thought stopping memberikan makna yang signifikan terhadap penurunan postpartum blues dan tingkat ansietas ibu postpartum dengan bayi prematur di ruang Perina - Nicu.

3. Tindakan keperawatan Ners juga memberikan makna yang signifikan terhadap penurunan postpartum blues dan tingkat ansietas ibu postpartum dengan bayi prematur di ruang Perina-Nicu.

Tindakan keperawatan Ners, terapi thought stopping dan terapi suportif memberikan makna yang sangat signifikan terhadap penurunan postpartum blues dan tingkat ansietas ibu postpartum dengan bayi prematur dua kali lebih besar dibandingkan pemberian tindakan keperawatan Ners.

\section{REFERENSI}

Agustarika, B.(2009). Pengarub Teraeitropi Thought Stopping terhadap Ansietas Klien dengan Gangguan Fisik di 
RSUD. Kab.Sorong. FIK UI. Tesis. Tidak dipublikasikan

Bobak,I.,Lowdermilk, D.L., Jensen, M.D., \& Perry, S.E., (2005). Buku ajar keperawatan maternitas. (4 ed). (R.Komalasari, Penyunt., M.A. Wijayarini, \& P.I. Anugerah, Penerjemah). Jakarta, Indonesia: EGC

Eutrope, Thierry, Lempp, Laurence. ( 2014). Emotional Reactions of Mothers Facing Premature Births:Study of 100 Mother-Infant Dyads 32 Gestational Weeks. Journal Plos one, Vol.9, No.8

Lindberg, B., \& Ohrling, K. (2008). Experiences of Having a Prematurely Born Infant From The Perspective of Mothers in Northern Sweden. International Journal of Circumpolar Health, 67 (5), 461-471.

Melynk, B.A., et al. (2007). Reducing Premature Infants Length of Stay and Improving Parents Mental Health Outcomes With The Creating Opportunities for Parent Empowerment (COPE) Neonatal Intensive Care Unit Program: A randomized, Controlled Trial. Pediatrics, 118, 1414-1427.

Murray, S. S., \& Mckinney, E., S. (2007). Foundations of Maternal-Newborn Nursing. 4th edition. Singapore: Sounders Elsivier.

Naikare, V.R., Kale., P, Kanade., A.B. (2015). Thought Stopping Activity as Innovative Trend to Deal with Stresses. Journal of Psychiatric Nursing 2015; 4(2):63-66

Pilliteri, A. (2010). Maternal child bealth nursing: Care of the Childbearing and childrearing family (6rd ed). USA: Lippincott Williams \& Wilkins Inc.

Stuart, G.W., Keliat, B.A. (2013). Prinsip dan Praktik Keperawatan Kesehatan Jiwa Stuart. (Edisi Indonesia). Mosby. Elsevier

Syaifuddin. (2006). Buku Acuan Pelayanan Kesehatan Maternal dan Neonatal. Yogyakarta : Yayasan Bina Pustaka

Townsend, MC. (2009). Psychiatric Mental Health Nursing. (6th Ed). Philadhelpia:Davis Company

Varcolis, E.M. (2006). Foundations of Psychiatric Mental Health Nursing. A Cliinical Approach, (5th ed), St. Louis. Elsevier

Varney H, Jan M.K., Carolyn L.G. (2006). Buku Ajar Asuban Kebidanan, Edisi 4, volume 1. Jakarta : EGC

Videbeck, S.L. (2011). Psychiatric Mental Health Nursing. (4rd Ed). Philadhelpia: Lippincott Williams \& Wilkins.

Viederman. (2008). A Model for Interpretative Supportive Dynamic Psychotherapy. Journal of Psychiatry 71(24). New York

WHO. ( 2010 ).Fenomena kematian bayi . diakses tanggal 01 Maret 2015. http://health.detik.com

WHO. (2013). Perawatan Khusus Optimalkan Bayi Prematur. Diakses $08 \quad$ Maret 2015. www.mediaindonesia.com 